\title{
GLOBALISATION, WESTERN HEGEMONY AND CHINESE PARTICULARISM: IMPLICATIONS FOR SOCIAL WORK AND SOCIAL POLICY ${ }^{1}$
}

\section{Vishanthie Sewpaul}

\section{INTRODUCTION}

China's macroeconomic policy, which has recently been described by Chinese policy makers as "a socialist market economy" (Jie, 2004; Zhixin, 2004) but which effectively emerges as a struggle to balance socialism with free market capitalism, contains inherent contradictions. Socialism and free market capitalism are ideologically inconsistent with each other and share diverse historical roots, with many socialist revolutions being a reaction to the marked economic disparities and class differences engendered by capitalist practices. China's phenomenal economic growth, its obvious neoliberal capitalist practices and its attempt to balance these with those of socialist ideology and practices raises a critical question: would China implode under the weight of its own contradictions or do these contradictions hold the potential to chart a new development paradigm for the rest of the world? China is the country perhaps with the singular ability to contest the unipolar imperialism of the United States; however, the form(s) that this might take remains unclear. In its international relations, China is driven by pragmatism in respect of foreign trade opportunities, the need for support of the international community to maintain peace and domestic stability, and its need for energy resources.

Despite opening itself to the rest of world, engaging in free trade, and an ever increasing dialogue between the East and the West, China essentially remains a single-party state. Views about the Chinese Communist Party (CCP) are clearly divided both within and outside China. Much of the West tends to represent China as a caricature of Asia - authoritarian and patriarchal - a caricature unfortunately reinforced by some of our colleagues within China and one that I have contested (Sewpaul, 2007). That China is one of the most rapidly developing and changing countries in the world, even as it emphasises the need for social stability and continuity, is indisputable. Rob Gifford (2007:26) asserts: "Finally, finally, after a century Shanghai is rising, as China is rising, on the back of a century of humiliation before 1949, and then half-century of Communist chaos that came after it."

The socio-economic and political reforms made in China over the past twenty years or so, which have seen a burgeoning of social work education and practice, remain unprecedented in the $21^{\text {st }}$ century and there is certainly much to celebrate in China's development. According to the China Daily (18 June 2007), China produces over 10000 social workers from 200 universities across the country, with the government having passed legislation in 2006 regulating the certification of social workers. These are phenomenal leaps within a twenty-year history of social work, surpassing that of many Western countries, where social work has a far longer history. In a country of over 1,3 billion people, struggling to introduce systems to widen social security as state-owned enterprises (SOEs) and a centralised, planned economy

\footnotetext{
${ }^{1}$ This paper was presented at the East China University of Science and Technology (ECUST), Shanghai on its $60^{\text {th }}$ anniversary in October 2007. Colleagues in Social Work celebrated the occasion by hosting an international conference with the theme: "East-West dialogue: Challenges for Social Work and Social Policy". I am indebted to the ECUST for facilitating my participation at this special event.
} 
disintegrate; as China becomes more integrated into the global socio-economic and political order; as China evolves policies and practices that embrace constitutional reform and human rights practices; as the rate of rural-urban migration escalates, and with a predicted escalation in the rate of HIV/AIDS, there are bound to be enormous challenges for social work as a relatively new discipline, with perhaps a key question being: how do social workers position themselves among the varied competing interests?

\section{SOCIAL WORKERS - A METAPHOR FOR "VOICE" IN CHINA}

Social work across the world is characterised by conflicting and competing interests, with both historical and contemporary system-stabilising and system-destabilising functions, with a predominance of system-stabilising functions (Hölscher \& Sewpaul, 2006; Parton, 1996; Pearson \& Phillips, 1994; Sewpaul, 2007). All social workers face challenges about where they pitch their interventions - the micro and/or macro level; do we work within, alongside or outside of the state apparatus, and what should our relationship with the state be. Social work in China has its genesis within all of China's extreme contradictions of market and political reform, and I raise the question of whether or not these contradictions might produce more acute dilemmas for Chinese social workers and subject them to greater self-reflexivity, compared to their counterparts in Europe and the USA, who "perhaps have fairly settled views of what social work is and what it means to provide good social work education" (Payne, 2001:41). Contrary to the "settled views" of the West, it is perhaps the self-doubt of Chinese social work that holds the potential for fluidity and dynamism that might contribute to innovation in social work education and practice. While Chinese social workers have opened themselves to the values, principles and practice scope embodied in the international definition of social work (IASSW, 2006) and the global standards for social work education and training (Sewpaul \& Jones, 2005), they have at the same time challenged concepts and highlighted possible contradictions that exist (Jia, 2007; Leung, 2007; Yip, 2004a).

Social work, in all contexts, gains its specific mandate in speaking for public interests. But what happens when the dominant ideology endorsed by the ruling Party conflicts with the will of the populace? Unlike loyalists who adopt blind faith or use the system for self-gain, or dissidents who make a career out of criticising and exiting the system (Yongnian, 2007), social workers who represent "voice" are willing to be constructively and dialectically engaged in advancing the interests of the public and more specifically of the poor, embracing the overall development of the country. They are aware of complex power dynamics in society, are willing to mediate between competing interests and to regulate power as they work toward peaceful coexistence and development where change and development are not necessarily inconsistent with stability and harmony. In representing "voice" in China, social workers need to recognise the enormous progress in China's move toward constitutional endorsement of human rights, the affirmation of women's right to equality, the right to private property and ownership, the relative freedom from state interference in day-to-day life and China's efforts toward the provision of social security during the period of reform. But as "voice" in China, social workers need to ask how policies and practices can be enhanced and entrenched, what the gaps are, and they need to ask, in the mode of constructive criticism, what needs to be challenged and changed. Jia (2007:99) speaks of the merits of dialogue with the West and the huge advances that are being made in China with "countless examples" such as: "the revocation of asylumseeker deportation policy, the adoption of social assistance legislation, the protection of education rights of peasant migrant workers and their children in urban centres, social support to people with HIV/AIDS and their families, rural community development [and] urban 
community services", with the impact being "clearly felt by social work educators, practitioners and academics".

Social workers in China must draw on its unique history and harness the positive, contradictory and competing strands of its particular traditions and values, and the multiple identities within the Chinese context to develop vibrant, locally specific social work education and practices, and social policies to meet the needs of local communities (Sewpaul, 2007). Given the impact of global forces on local communities, this would demand that social workers and social policy makers develop a critical understanding of China's role in international affairs that would truly allow them to represent "voice" in China. Social work developing and professionalising at a rapid rate, with the support of the CCP (Jia, 2007), might strategically position it to strengthen nation-building, stability and harmony without compromising human and social development, and the pursuit of social justice and human rights. China's neoliberal capitalist expansion, which generates both great wealth and huge inequalities, that render women and children most vulnerable, must pose a challenge to social workers' efforts to balance competing interests.

\section{A "SOCIALIST NEOLIBERAL CAPITALIST ECONOMY": TENSIONS AND CHALLENGES}

Since the period of reform in 1978 China has seen a shift from a centrally planned economy, with an increasing role for independent macro-economic practices. In this shift China has been making some efforts to reconcile two counter-posed policies - one based on political and to a lesser extent financial repression (for some groups of people), and the other advancing a free market economy characterised by reduced state expenditure and a greater role for a liberalised financial sector. Such reconciliation in China's early reform has had positive impacts, on the whole, on China's poverty-reduction efforts in designated geographic areas (Chandrasekhar \& Ghosh, 2006; China Human Development Report, 2005; Gifford, 2007). According to the World Bank (WB) (cited in Gifford, 2007), China has lifted 400 million people out of poverty since 1978 - this is no mean feat! Chandrasekhar and Ghosh (2006:42) conclude that: "The Chinese experience makes it clear that such either-or dichotomies are not inevitable and that a pro-poor macro-economic framework must provide a role for state policies pursued within an area of control ensured with state regulation". The rate of poverty reduction is attributed to state control of financial institutions, the continuation of some SOEs, "controlled" trade and the creation of opportunities for export-oriented employment generation. Comparing China's reform with that of India where macro policies adversely affected employment generation, these authors argue that "macroeconomic flexibility in a market-driven environment is not the best recipe either for growth and stability or for poverty reduction" (Chandrasekhar and Ghosh, 2006:41).

This kind of reconciliation, if it did indeed represent a linear and egalitarian growth pattern with a focus on people's development, would mean that China holds the potential to chart a new development path for the rest of the world. But is the centre holding? Can two seemingly inconsistent and contrasting policies be sustained in the long run? The inconsistency appears to lie in a neoliberal capitalist state being run by a Communist party. Despite the Party claims to the existence of a socialist market economy, one is hard pressed to discern anything really socialist about contemporary China. Gifford (2007) contends that in terms of social welfare, China is less socialist now than Europe and he comments on the near complete breakdown of government subsidies for essential services in rural areas. 
Of singular importance is China's accession to all the demands of the World Trade Organisation (WTO), to which China gained entry in November 2001 (Halverson, 2006), reflecting the "advancing tide of global hegemony by the capitalist West" (Mohanty, 1998:2). Among the conditions agreed to by China are the following: reduced tariffs on industrial goods; the liberalisation of a number of service sectors that were previously closed or severely restricted to foreign investment; elimination of export subsidies on agricultural goods, with a loss of about 11,3 million jobs in the agricultural sector; making subsidies to state-owned enterprises subject to countervailing duty actions; elimination of export subsidies on industrial goods; demands for Western rules of law in terms of transparency, accountability and intellectual property protection (Halverson, 2006), all of which are similar to the kinds of market discipline imposed by the International Monetary Fund (IMF).

As China makes the transition from a socialist to a free market ideology, there are dangers that it might fall prey to all aspects of neoliberal democracy, with its concomitant neoliberal capitalism, and thus begin to emulate its nemesis - the United States. As China has acceded to WTO demands for free rather than fair trade, as trade barriers have become more liberalised, as Special Economic Zones proliferate in China to grant special concessions to multinational corporations that exploit labour (Boos, Boos \& Sieren, 2003) social workers need to ask: who benefits from China's rapid economic growth and at what costs, especially for those most vulnerable in Chinese society - the rural poor, rural-urban migrants, women and children?

As in South Africa, where the economic boom has not benefited the large majority of poor people who have taken to the streets in protest, China's shift from the pre-reform era, which focused on promoting equality and limiting incoming differences (over political equality and freedom), to its largely profit-driven economic miracle has provided fertile ground for growing inequality and discontent. According to the Chinese Communist Party's (CCP) statistics, there were over 80000 incidents of rural unrest in 2005 and an estimated 200 incidents on a daily basis, most of them linked to growing inequality (Gifford, 2007). While Western liberal democratic theory asserts the priority of freedom over equality (Mohanty, 1998), and Neocosmos (2006), writing within the more radical tradition, asserts that freedom to think is the most basic and fundamental of freedoms, gross inequalities clearly hamper the exercise of freedom (Amin, 2001; Sen, 1999).

Sen (2005) places a high premium on the value of freedom to think and on the importance of argumentation, dialogue and debate - on democratic participation. Sen (2005:201) asserts that "the weakness of voices of protest has helped to make the progress of social opportunities unnecessarily slow." But he argues that while individual agency and freedom are central to addressing all forms of social, economic and political deprivations, "the freedom of agency that we individually have is inescapably qualified and constrained by the social, political and economic opportunities that are available to us" (Sen, 1999:xi-xii). He contends that the removal of substantial unfreedoms, such as lack of freedom to access food, shelter, health and education is constitutive of development. Samir Amin (2001) asserts that neoliberal capitalism undermines true democracies and in view of the issues that he raises we need to ask: if democracy is about human rights, social justice, people participation and respect for human dignity, where is its convergence with a marketplace that has no room for justice and compassion, that creates indifference to inequality, hunger, exploitation and suffering; that excludes the voice of the Other, with highly centralised power negotiated by the WB, IMF, WTO and by the world's superpowers? If information is central to a deepening democracy, how can there be democracy when information and the very ideas that we generate are 
commodified? What is the convergence of democracy and the market when intellectual property rights (IPRs), incorporating patent laws, designed purely in the interests of profit, allow people in the Two-Third World to die?

While liberal democracy promises individual freedom, such freedom for the majority of people in the Third World means constricted choice, leading to illness, starvation, hunger and death. While acknowledging the remarkable developments in China, Gifford (2007) poignantly details the poverty of rural China and the degradation in centres of "raw industrial capitalism" (2007:37), where "workers are locked in and forced to toil in near slave-like conditions" (2007:38), and speaks of the shift from the "tyranny of poverty into ... [the] tyranny of choice."

There are calls for social workers to envision another world based on social activism, on popular people participation and on emancipatory politics (Fergusson \& Lavalette, 2006; Sewpaul, 2007). Such social activism does not always have to be adversarial. Jia (2007:100) points out that social workers in China have worked with the government to include social work into "the master plan for nation building" and that social work education has contributed to advocacy and public policy making over the past twenty years. Implying that social action, involving confrontation, is part of the repertoire of social work skills in China, Jia (2007:99) warns us about the dangers of analysis from afar as Western social workers "imagine that confrontational strategies are prohibited in China" (my emphasis). As in the West, the radical thrust, embracing social and political action, is not commonplace in China, but the use of such activism is not precluded (Jia, 2007; Leung, 2007). The inequalities, consequent upon China's capitalist globalisation, might increasingly call upon social workers to engage in social and political action.

\section{THE CONSEQUENCES OF CHINA'S CAPITALIST GLOBALISATION}

Having fallen prey to the forces of capitalist globalisation, China's promise of socialism seems to be relegated to the backburner. China's accession to WTO demands has produced an unprecedented impetus for legal reform, one based on the rule of law rather than power relationships, despite the deep actual and ideological influences of the CCP and the National People's Congress (NPC). While there is an official commitment to promoting democracy, with some evident measures of success, e.g. the promulgation of the Administrative Litigation Law, which allows people to legally challenge administrative decisions and the establishment of the Supreme People's Court (SPC) which oversees China's judicial system (Halverson, 2006), the CCP uses repression to stifle social discontent and tries to ensure political allegiance in the name of stability and social harmony. China has increasingly recognised the roles of NGOs in promoting the interests of people and in delivering social services, yet in its effort to retain control the government is wary of the potential of such groups to promote instability and thus limits the activities of NGOs, and represses religious groups perceived to be a threat to the system (Dickson, 2003; Gifford, 2007). NGOs in China represent a double-edged sword; they have the potential to help as well as hurt the CCP.

On the whole, China is accelerating an economic and political process that will remove the government even further from vast areas of people's lives. In this respect Halverson (2006:14) raises the following question: "[...] whether the weakening of government control and economic dislocation, resulting from economic reform, will ultimately produce mass unrest and further repression or whether it will produce continued economic growth and gradual political liberalisation", while Lewis and Litai (2003:928) ask "whether the reforms themselves [might] delay or accelerate the end of one-party rule." 
There are no easy (if any) answers to these questions. The CCP has committed itself to a "socialist market economy", to building socialism with Chinese characteristics. The anomaly, in the process, is that while China has moved toward an unbridled, consumerist capitalism, it has retained some of the centralist political repression of the past and this is not a catalyst for democratic change (Dickson, 2003). While state domination, regulation and denial of individual freedoms might be justifiable in achieving a collective solidarity and equality, the removal of these latter objectives means that state comes to represent negative intervention. Mohanty (1998:6) argues that the "market economy is considered a canon of liberal democracy in the age of capitalism. In China it may have achieved economic growth, but it has caused serious social inequalities."

According to the World Bank (cited in Han, 2007), rural China's Gini coefficient (a measure of equality with 0 being perfectly equal and 1 being totally unequal) increased from 0,239 in 1981 to 0,340 in 1995 . Pointing to the rising social costs of economic growth, Lewis and Litai (2003:927) assert that "these underlying changes that accompanied dramatic economic growth created serious internal problems, and these problems in turn forced the leadership to undertake more open political reforms or face rising dissent, deepening corruption and an even greater loss of party authority [...] the forces causing instability have been matched by those advancing broad economic growth." These authors cite five categories of disenfranchised people - the peasants, urban workers, minority religious groups, demobilised soldiers (the majority of whom had lost their jobs with the reform or privatisation of SOEs) and some radicalised intellectuals who combined have "explosive potential", prompting greater control from Beijing (Lewis \& Litai, 2003:932), which in turn has the potential to exacerbate rather than diminish social disobedience and instability. China's economic reform has contributed to the commodification of essential services and of society, especially women who are economically and sexually exploited and subject to domestic violence.

\section{CHINA'S SOCIAL SECURITY REFORM}

Concomitant with its market economy, China has made dedicated efforts to consolidate a social security system consisting broadly of: social insurance and social assistance (Jie, 2004; Yanyin, 2004; Zhixin, 2004). The former includes medical insurance, pension, unemployment insurance, work injury insurance and maternity insurance. The latter consists of a minimum living standard scheme for urban residents, minimum living standards programme for semirural residents, assistance to those in difficulty or suffering from disasters and povertyalleviation projects (China Human Development Report, 2005). The social security measure that has contributed to the greatest reduction in urban poverty to date is the Scheme of Minimum Living Standards for Urban Residents implemented in 1999 (Yanyin, 2004), which represents the most positive step in promoting "universal citizenship and equality of social rights among citizens" (China Human Development Report, 2005:9). All urban residents have a right to apply - with the place of Hukou (place of residence) being the only restriction.

Social security is deemed to be a prerequisite for continued stability and harmony, both of which are highly valued in Chinese society. The impact of economic reform is acknowledged by Party officials. Yanyin (2004:12), the Vice-Minister of Civic Affairs in China, asserts: "The recent years saw increasing laid-offs and unemployed, widening the gap between the rich and the poor and the growing needy residents, as a result of the transformation in the system and transition of the economy." While China's provision of a range of social security benefits to its huge needy population is laudable and has reduced poverty to some extent, we must be mindful of possible unintended consequences of even good policies. According to the China Human 
Development Report (2005), social security programmes "have limited coverage and are available to a privileged few. At the same time, the proportion of social aid and service for the underprivileged is shrinking over time". Providing compelling empirical evidence, the Report argues that there are urban-rural, gender (with women being the lesser beneficiaries) and regional biases in access to all forms of social security. It is not possible within the scope of this paper to provide full details. The following are some examples: the average social security expenditure per capita in urban areas was 10 times that of rural areas; more than $70 \%$ of the urban elderly were covered by the pension scheme compared with $3 \%$ of the elderly in rural areas. In this category the gender difference, even in urban areas, was notable, with male to female ratio being three to two and the amount of the pension varying depending on gender, location of residence and workplace ownership. The amount received by urban residents was $20 \%$ higher than for those in the rural areas and the per capita pension for the non-farming elderly was $110 \%$ higher than for farming residents. Pension for urban males was $40 \%$ higher than for urban females, while rural males received 52\% more than rural women. Only $2 \%$ of rural migrant workers had unemployment insurance, while reforms of SOEs and increasing informal employment meant that the proportion of people with no medical insurance increased dramatically - from $27,3 \%$ in 1993 to $44,8 \%$ in 2003. Given social work's pursuit of equality and social justice, it is these kinds of inequalities that need to be challenged.

Citing Chen, Liu and Zhang, $\mathrm{Xu}$ (2004) cogently argues that while migration control via the Hukou system is still entrenched, the government now uses welfare policy to control ruralurban migration, and it is this paradoxical and pragmatic consequence of social security reform that social workers can take up in reviewing it. As policies on social security, health care and housing discriminate against rural-urban migrants, there is a huge gap in welfare benefits for them. Citing the results of a Chinese Academy of Social Science study, the China Human Development Report (2005) reflects that the per capita income of migrant households was only $65 \%$ of those of local urban households. Given their lack of status in the Hukou system, rural migrants lose their safety nets. Xu (2004:295) elucidates this as follows:

It is China's new social welfare system, which continues to privilege urban residency, that encourages rural-urban migration. Instead of setting barriers to newly arrived migrants, the welfare system facilitates urbanization by creating more jobs for them. Already established urban residents are laid off and replaced by migrants, since this helps entrepreneurs to lower their costs; hiring someone who already resides in an urban area would cost employers more in terms of paying mandatory welfare benefits. Discriminatory treatment in China's new social welfare system does not prevent rural people from moving to the cities, as long as they believe there is increased opportunity for increased income.

It is thus a system that disadvantages both migrants and established urban residents. While urban residents get laid off, rural migrants are exploited, have to work long hours under atrocious and hazardous conditions that predispose them to severe medical problems and they live in poor housing conditions. All of this underlies the social unrest and social disobedience, which exacerbate ethnic divides, thus compromising the very goals that social security aims to achieve - stability and harmony.

That China is increasingly moving toward a culture of consumerism and that, as with all neoliberal capitalist societies, money and the good life become prime pursuits as the average Chinese person aspires toward a promising life like that of the American West, is evident that this is producing in its wake a crisis of values for many Chinese. 


\section{GLOBALISATION, WESTERN HEGEMONY AND CHINESE PARTICULARISM: CHALLENGES FOR SOCIAL WORK}

The theme of the international conference "East-West dialogue" endorses the merits of dialogue across borders, as do Jia (2007) and Leung (2007), reflecting China's growing international interdependence and the opportunities and vulnerabilities that this brings, but it also in line with the stereotypical dichotomising of different "types" of worlds - North-South and East-West, with conventional characteristics attached to these, which are increasingly being challenged in a globalising world. There is a general tendency to pit Asian values against Western values (see Hutchings and Taylor, 2007), presupposing an absence of Asian values in the West and vice versa, a tendency that I have strongly argued against (Sewpaul, 2007). In a rapidly globalising world, knowledge, culture and technology rapidly become globalised. There are both advantages and disadvantages to this, with social work borrowing knowledge from different contexts, which Jia (2007) and Leung (2007 rightfully assert has merit on condition that it is done with reflexivity and caution.

Leung (2007:393) contends that the polarisation of the East and the West serve as blocks to mutual understanding and collaboration and claims that "Globalisation means that China has to consider common international practice, standards and law, rather than emphasise its uniqueness." The debates between the universal and the particular are complex and the solution is to see the particular in the universal and the universal in the particular; the world is not an either/or place (Sewpaul, 2005). A total de-emphasis on the particular can produce a crisis of values. The downside of capitalist globalisation is that with the decline of Confucian and Communist values, it has heightened individualism and left a moral vacuum - the creation of ziwo yidai, the "Me Generation". Gifford (2007:23) cites a Chinese radio show host, Ye Sha, who said: "The previous life was too slow, for sure. But now it's too fast [...] the morality, the rituals, the ethics. Now it isn't emphasized enough. No one knows how to be a person anymore. We are training technicians. We are not training people."

Despite the growing convergence between the East and the West, Hutchings and Taylor (2007) assert that "Chinese culture" 2 rests largely on traditional Asian values of family and the collective; that social work in China is predicated on the values of respect for authority; is governed by authoritarian state apparatus; and that social workers in China do not challenge authoritarianism and do not engage in social action. These views have been challenged (Jia, 2007; Sewpaul, 2007). It is the "specialness" of Asian values, traditions and respect for authority at both micro and macro levels that has often been used as justification for suppression of civil and political rights and freedom.

Chung and Haynes (1993) and Yip (2004a; 2004b) speak of hierarchical, patriarchal and authoritarian structures as virtues to be respected and preserved. Chung and Haynes (1993) idealise the Confucian "value of male heirs, who are expected to perpetuate the family line", while Yip (2004b:482) asserts that "those in power are obliged to love and protect their followers, children and wives. Those in powerless positions, the followers, children, and wives, are obliged to respect their kings, father, and husbands" (my emphasis). The obvious patriarchal messages and gender discrimination in these statements are unconditionally accepted, yet constitutionally repelled in China. Confucian philosophy recognises the universal

\footnotetext{
${ }^{2}$ In an earlier paper (Sewpaul, 2007) I challenged Hutchings and Taylor's essentialising discourse on culture, pointing out that just as there is no monolithic Western culture and Western social work, there is no single Chinese culture and Chinese social work.
} 
dignity of human beings, the morally autonomous individual and it affirms the place of legitimate protest in the face of injustice. Sen (2005:135) poignantly addresses the issues and concerns in the following manner:

Even if it were shown that freedoms of this kind have been less important in Asian thoughts and traditions than in the West, that will still be an unconvincing way of justifying the violation of these freedoms in Asia. To see the conflict over human rights as a battle between Western liberalism on one side and Asian reluctance on the other is to cast the debate in a form that distracts attention from the central question: what would make sense in contemporary Asia?

Sen $(1999,2005)$ questions the assumption that greater importance has been placed on tolerance and individual freedom in the West than in Asia, asserting that in making this assumption there is a tendency to extrapolate backwards from the present. Emphasis on liberty, freedom and reason can hardly be seen as part of an age-old Western heritage, given their links to the period of Enlightenment and to more recent developments. There are ample examples of lack of tolerance of diversity in both the East and the West, and examples of Asia's greater levels of tolerance as well - a view supported by Kirby (2004), who asserted that the realms of freedom are not unique to Western civilisation.

We must be careful about reifying and idealising Asian culture based on collectivism, respect for family, and as embodying unifying and holistic principles and intuitive functioning as opposed to Western culture, which is represented as fragmented, individualised and reductionist (Sewpaul, 2007). Citing Heus and Pincus, Chung and Haynes (1993:28) assert that "Generally, it is accepted that Western culture orientates towards the pragmatic and individualistic, while Eastern culture is idealistic and collective." Given the impact of colonialism in undermining the intellectuality and self-confidence of colonised peoples and the destruction of local traditions and cultures, one can well understand such an approach that attempts to repudiate "cultural conceit as well as imperial tyranny" (Sen, 2005:107). Perhaps as a reactionary measure, tradition gets to be upheld as the core of an authentic indigenous culture; an emancipatory alternative to a hegemonic Western culture. Thus Chung and Haynes' (1993) emphasis on the Chinese concepts of "love, humanity, perfect virtue and benevolence", implying that these are not part of Western thought and practices. These authors go so far to dichotome Western culture as "low-context culture" that is "left-minded" and Eastern culture as "relatively high context" and "right-minded" (Chung \& Haynes, 1993:38).

Sen (2005:85) calls for an approach that distinguishes between Western hegemonic and imperialist practices and Western civilisation:

The need to resist colonial dominance is, of course, important, but it has to be seen as a fight against submissive compliance, rather than as a plea for segregation and localism. The so-called "post-colonial critique" can be significantly constructive when it is dialectically engaged - and thus strongly interactive - rather than defensively withdrawn and barriered.

Simply because certain ideas, values, theories and technologies are linked to the West, they should not be condemned or rejected. Moreover, given the historical, cultural and intellectual interconnections across the globe, it is often hard to differentiate what is Western and what is Eastern. Sen (2005) goes on to cite specific reasons why dichotomising the East and the West and rejecting anything foreign is based on flawed premises. Firstly, what constitutes "Western 
science" is difficult to delineate. Europe or America is not its sole custodian, given that developments in mathematics and science in the West drew chiefly from earlier developments in Arabia, China and India. Secondly, irrespective of where discoveries were made, their import is generally of universal significance. We must acknowledge early inventions in China that have contributed to the West, including paper, gunpowder, printing, the compass and deep drilling techniques - all used by the West, with no apology, in its imperialist pursuits. Gifford (2007:45) argues that it was China's rapid advancement before the $12^{\text {th }}$ century that "was one of the preconditions for Europe's rise."

\section{CONCLUSION}

If China's extreme contradictions are not to lead to disastrous consequences, it is vital that social workers and social policy makers become "voice" in China. Global technology allows social workers both within and across nation states to represent "voice". We can instantaneously, from the comfort of our living rooms, witness the dehumanising treatment of people in Burma, Sudan and Zimbabwe, and learn of China's unacceptable support of, and links with, such regimes (Eisenman, 2005) as much as we learn of South Africa's equally unacceptable quiet diplomacy toward Zimbabwe and the violent protests that rock the streets of South Africa; and it is globalised technology that allows us to develop networks of support for social justice and resistance against oppression and torture.

China's remarkable economic growth and its entry into world politics and economics render it a contender in challenging the unipolar imperialism of the US, especially in South-East Asia (Bert, 2003). China is perhaps singularly the country with the potential to do so, but whether or not it has the political will to do so and what role it will play is open to debate. If China is to chart any new development path, it needs to review its current socio-economic, welfare and foreign policies, and try to remain true to its promise of socialism. Current trends reflect that China might be acceding to US norms of liberal democracy, the limitations of which are addressed in this paper. If China has to emulate the US with regard to consumption, the speculation is that it will deplete its natural resources and exacerbate environmental degradation (Brown, 2007), with China being the world's main centre of global manufacturing and hence global warming and loss of biodiversity (Economy \& Starr, 2003; Giessmann, 2006; Gifford, 2007).

China, like the US, must commit to responsible and sustainable development. China and the US remain rivals on many issues, with the US being highly critical of China's violation of political rights, but they are (unlikely) bedfellows on some fundamental human rights issues. Both the US and China in 1998 opposed the draft treaty for the International Criminal Court, and in May 1999 both countries attempted to block a resolution at the United Nations High Commission on Refugees (UNHCR) calling for a moratorium on the use of the death penalty (Dalpino, 1999). Chinese policy makers can help shape policies that contribute towards China creating a world with multi-polar sites of power, advocating that China align its economic power to a political will and power to work in the interests of humanity, both within and outside of China, and earn the true respect of Chinese citizens and the international community. Failure to do so might mean that China (like the US with its well-publicised atrocities, especially in countries of the developing world - the contemporary exemplar being the war on Iraq) becomes the bane of the international community. China's aspiration must move beyond merely joining the world order towards changing it. We must accept, as Gungwa (2003:30) says, that Chinese domestic reforms cannot be separated from "the matrix of international relations." 
China is one of the more recent examples of the shift from socialism to a free-market ideology which has seen in its wake unprecedented wealth creation, with "dramatic uneven development across different regions and populations" (Chi, 2005:373), and it is this growing inequality that must remain at the centre of policy debates and social workers' concerns. After all, socioeconomic differences, rather than poverty and ethnicity per se, are factors in global catastrophes such as war and genocide, with excessive inequality between the haves and havenots clearly contributing to conflict (Diamond, 2005).

\section{REFERENCES}

AMIN, S. 2001. Imperialism and globalization. Monthly Review, 53:2. Available: http://www.monthlyreview.org/0601amin.htm.

BERT, W. 2003. The United States, China and Southeast Asian security: a changing of the guard? New York: Palgrave MacMillan.

BOOS, C., BOOS, E. \& SIEREN, F. 2003. The China management handbook. New York: Palgrave MacMillan.

BROWN, L.R. 2005. Learning from China: why the Western economic model will not work for world. Available: www.earth-policy.org/Updates2005. [Accessed: 27/06/2007].

CHANDRASEKHAR, C.P. \& GHOSH, J. 2006. Macroeconomic policy, inequality and poverty reduction in India and China. Available: www.networkideas.org/working/oct 2006/05_2006pdf. [Accessed: 27/06/2007].

CHI, I. 2005. Social work in China: guest editorial for the special issue. International Social Work, 48(4):371-379.

CHINA DAILY 18 June 2007. 3 Million social workers needed. Available: www.china.org.cn/english/china/214189.htm.

CHINA HUMAN DEVELOPMENT REPORT. 2005. The state of equity in China: social security and public expenditure. Available: www.undp.org.cn/downloads/nhdr2005/ 08chapter4.pdf. [Accessed: 20/06/2007].

CHUNG, D.K. \& HAYNES, A.W. 1993. Confucian welfare philosophy and social change technology: an integrated approach for international social development. International Social Welfare, 36:37-46.

DALPINO, C. 1999. Human rights in China. Policy Brief \#, 50. Available: www.brookings.edu. [Accessed: 27/06/2007].

DIAMOND, J. 2005. Collapse: how societies choose to fail or survive. London: Penguin Books.

DICKSON, B.J. 2003. Red capitalists in China: the party, private entrepreneurs, and prospects for political change. New York: Cambridge University Press.

ECONOMY, E. \& STARR, C.V. 2003. China's environmental challenge: political, social and economic challenges. Available: www.cecc.gov/pages/roundtables/012704/economy.php. [Accessed: 02/07/2007].

EISENMAN, J. 2005. Zimbabwe: China's African Ally. China Brief, 5(15). Available: www.jamestown.org/print. [Accessed: 26/09/2007]. 
FERGUSSON, I. \& LAVALETTE, M. 2006. Globalisation and global justice: towards a social work of resistance. International Social Work, 49(3):309-318.

GIESSMANN, H.J. 2006. New powers for global exchange: China's role in the emerging world order. Friedrich Ebert Stiftung Briefing Paper, October. Available: www.fesglobalisation.org/publications/fes.

GIFFORD, R. 2007. China road: a journey into the future of a rising power. London: Bloomsbury Publishing.

GUNGWA, W. 2003. To act is to know: Chinese dilemmas. Singapore: Times Media Private Ltd. Eastern Universities Press.

HALVERSON, K. 2006. China's WTO accession: economic, legal and political implications. Available: www.bc.edu/schools/lawreviews/meta-elements/journals/bciclr/ 27_2/06_TXT. [Accessed: 03/07/2007].

HAN, T. 2007. China: a shared poverty to uneven wealth? Available: http://www.gwu.edu/index.cfm. [Accessed: 09/02/2007].

HÖLSCHER, D. \& SEWPAUL, V. 2006. Ethics as a site of resistance: the tension between social control and critical reflection. In: HALL, N. (ed). Social work: making a world of difference. Berne: IFSW \& Fafo.

IASSW. 2006. International definition of social work. Available: Error! Hyperlink reference not valid..

JIA, C. 2007. Correcting misconceptions about the development of social work in China: a response to Hutchings and Taylor. International Journal of Social Welfare, 16:98-101.

JIE, X. 2004. Financial support for sustainable development of China's social security. Available: www.undp-povertycentre.org.publications/cct/2china.pdf. [Accessed: 25/06/2007].

KIRBY, W.C. (ed) 2004. Realms of freedom in modern China. Stanford, CA: Stanford University Press.

LEUNG, J.C.B. 2007. An international definition of social work for China. International Journal of Social Welfare, 16:391-397.

LEWIS, J.W. \& LITAI, X. 2003. Social change and political reform in China: meeting the challenge of success. China Quarterly, 926-941.

MOHANTY, M. 1998. Development and democracy: the Indian and Chinese experience. In: CHUNG, T. \& THAKUR, R. (eds). Across the Himalayan Gap: an Indian quest for understanding China. New Delhi: Gyan Publishing House. Available: http://ignca.nic.in/ks_41.htm. [Accessed: 01/10/2007].

NEOCOSMOS, M. 2006. Development, social citizenship and human rights: rethinking the political core of an emancipatory project in Africa. Unpublished paper presented at the Centre for Civil Society, University of KwaZulu-Natal, June 2006.

PARTON, N. 1996. Social theory, social change and social work: an introduction. In: PARTON, N. (ed) Social theory, social change and social work. London: Routledge.

PAYNE, M. 2001. Social work education: international standards. In: HESSLE, S. (ed) International standard setting of higher social work education. Stockholm University, Stockholm Studies of Social Work. 
PEARSON, V. \& PHILLIPS, M. 1994. Psychiatric social work and socialism: problems and potential in China. Social Work, 39(3):280-287.

SEN, A. 1999. Development as freedom. Oxford: Oxford University Press.

SEN, A. 2005. The argumentative Indian: writings on Indian culture, history and identity. London: Penguin Books.

SEWPAUL, V. \& JONES, D. 2005. Global standards for the education and training of the social work profession. International Journal of Social Welfare, 14(3):218:230.

SEWPAUL, V. 2007. Challenging East-West value dichotomies and essentialising discourse on culture and social work. International Journal of Social Welfare, 16:398-407.

XU, Q. 2004. Review of book by Chen, A., Liu, G.G. and Zhang, K.H. (eds). 2003. Urbanization and social welfare in China. Burlington, VT: Ashgate. China International Review, 11(2):292-297.

YANYIN, Y. 2004. The minimum living standards guarantee system for urban residents in China. Available: www.undp-povertycentre.org.publications/cct/2china.pdf. [Accessed: 25/06/2007].

YIP, K. 2004a. A Chinese cultural critique of the global qualifying standards for social work education, Social Work Education, 23(5):597-612.

YIP, K. 2004b. The empowerment model: a critical reflection of empowerment in Chinese culture. Social Work, 49(3):479-487.

YONGNIAN, Z. 2007. Awaiting the appearance of the new type of intellectual. Translated by David Kelly. Available: www.zaobao.com/special/forum/pages5/forum zp070417a.html.

ZHIXIN, Z. 2004. Strengthening the social security system to promote coordinated economic and social development. Available: www.undp-povertycentre.org.publications/cct/ 2china.pdf. [Accessed: 25/06/2007].

Prof Vishanthie Sewpaul (PhD), School of Social Work and Community Development, University of KwaZulu-Natal, Howard College Campus, Durban, South Africa. 